Saudi Journal of Business and Management Studies Abbreviated Key Title: Saudi I Bus Manag Stud ISSN 2415-6663 (Print) |ISSN 2415-6671 (Online) Scholars Middle East Publishers, Dubai, United Arab Emirates Journal homepage: https://saudijournals.com

Original Research Article

\title{
Determinant of Stock Return and Its Implications on Market Value (Study on Construction and Building Issuer Year 2015-2019)
}

Pungky Soleha Millenianingsih ${ }^{*}$ and Bambang Mulyana

University of Mercu Buana, Jakarta, Indonesia

DOI: $10.36348 /$ sjbms.2021.v06i01.001

| Received: 23.12.2020 | Accepted: 08.01.2021 | Published: 13.01.2021

*Corresponding author: Pungky Soleha Millenianingsih

\section{Abstract}

The purpose of this study was to determine and analyze the behavior of stock returns and the market value of the company in the construction and building sub-sector listed on the Indonesia Stock Exchange for the year 2015-2019. The population in this research was 18 companies; using purposive sampling method obtained 8 companies as analysis units. The data analysis technique used is multiple linear regressions with the help of the SPSS v.26 application. The results of this study indicate that NWC has a negative significant effect on stock returns, DER has a negative significant effect on stock returns, ROA has a negative insignificant effect on stock returns, TATO has a positive insignificant effect on stock returns, and stock returns has an negative significant effect on PER.

Keywords: Stock Returns, Net Working Capital, Debt to Equity, Return on Assets, Total Assets Turnover, Price Earning Ratio.

Copyright ( $) 2021$ The Author(s): This is an open-access article distributed under the terms of the Creative Commons Attribution 4.0 International License (CC BY-NC 4.0) which permits unrestricted use, distribution, and reproduction in any medium for non-commercial use provided the original author and source are credited.

\section{INTRODUCTION}

Infrastructure development and physical projects in Indonesia, both privately owned and stateowned, have been massive since 2014. This condition should have a positive impact on construction and building companies as project executors. The following effect is certainly that many investors are interested in investing in the securities of the sector's companies in the hope of getting a more profitable return than investing in other sectors.

Figures 1 through 3 below show the development of average earnings, sales, stock return (dividend payout ratio), and market value (price earning ratio) in construction and building issuers during 20152019.

\section{Corporate Profit}

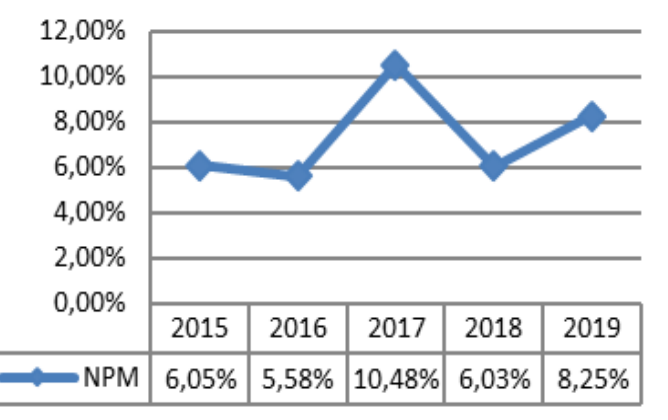

Fig-1: Average Profit of Construction and Building SubSector Companies for the Period 2015-2019 (Source: idx.co.id) 
The profit of construction and building issuers from 2015 to 2019 looks volatile with an increasing trend.

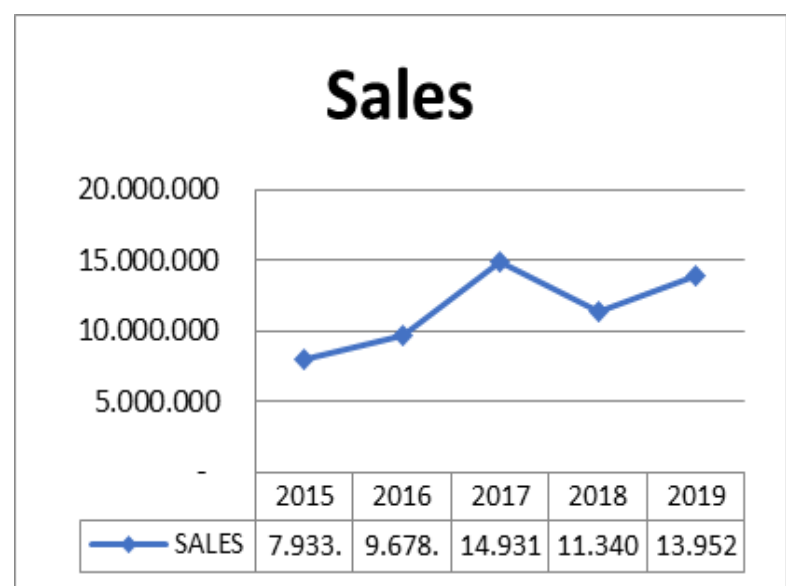

Fig-2: Average Sales of Construction and Building Sub-

Sector Companies for the period 2015-2019

(Source: idx.co.id)

The same conditions as profit occur in sales. Construction and building issuers experienced sales that tended to increase during the year 2015 - 2019.

Conditions in line with earnings also occurred in dividend payments to shareholders during 2015-2019 which fluctuated with an increasing trend.

\section{Dividend Payout Ratio}

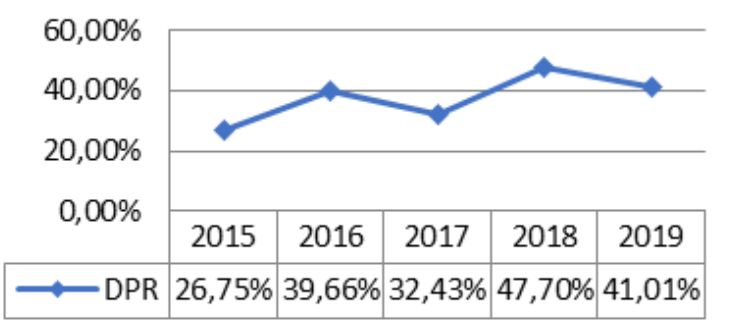

Fig-3: Average Dividend Payout Ratio of Construction and Building Sub-Sector Companies for the Period 2015-2019 (Source: idx.co.id)

The opposite condition with the three indicators above occurs in the market value of the company. From 2015 to 2019 the market value of construction and building issuers tends to decline.

\section{Market Value}

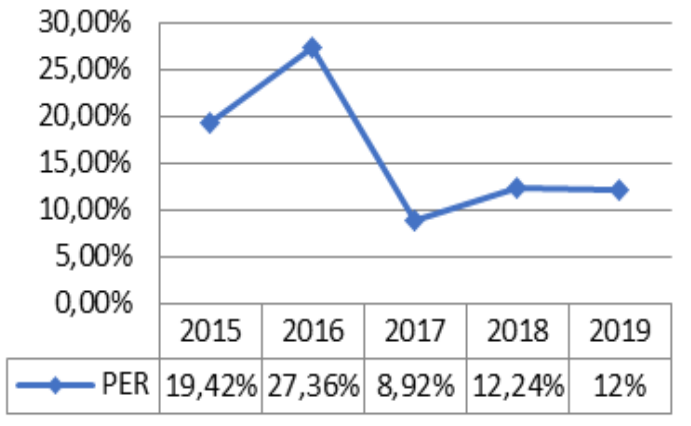

Fig-4: Average Market Value of Construction and Building Sub-Sector Companies for the Period 2015-2019 (Source: idx.co.id)

Based on the above phenomenon, it is worth suspecting that there are other factors that cause the value of the company tends to decrease.

\section{LITERATURE DEVELOPMENT Market Value}

The market value is defined as the estimated amount of money on the valuation date, which can be obtained from the sale and exchange transaction of property, between the buyer and the seller, in a bondfree transaction, whose marketing is carried out properly, in which both parties act on the basis of their understanding, prudence and without coercion. (3.1. SPI 1, SPI 2007).

This study uses the price earning ratio (PER) as a market value approach with the formula:

$$
\text { PER }=\frac{\text { Market Price per Share }}{\text { Earnings per Share (EPS) }}
$$

\section{Stock Return}

According to Aryanti [1], the return can be in the form of capital gain in the form of profit received due to the difference between the selling price and the purchase price of an investment instrument, or the level of divindend for investment in shares that are a form of performance results.

The stock form in the investment in the stock is divided by 2, which is:

\section{Capital Gain}

Capital gain is an advantage where the selling price is greater than the purchase price of a stock. The opposite condition results in investors experiencing capital loss. 
Pungky Soleha Millenianingsih \& Bambang Mulyana., Saudi J Bus Manag Stud, Jan, 2021; 6(1): 1-9

2. Dividend

Dividends are part of the company's net income distributed to shareholders based on the number of shares held. The dividend is one of the company's efforts in providing welfare to shareholders.

Measuring dividends paid by the company, dividend payout ratio (DPR) is used as a measuring instrument with the formula:

$$
\text { DPR }=\frac{\text { Dividend }}{\text { Net Income }}
$$

\section{Liquidity Ratio}

The liquidity ratio indicates the relationship between cash and other assets of the company and its current liabilities [3]. The increasing amount of working capital indicates a high level of liquidity [15]. The formula for calculating Net working capital is:

\section{NWC $=$ Current Assets - Current Liabilities}

\section{Solvency Ratio}

This ratio measures the use of borrowed capital to finance business projects [2]. The debt to equity ratio is used as a measure of solvency with the formula:

$$
\text { DER }=\frac{\text { Total Liabilities }}{\text { Total Equity }}
$$

\section{Profitability Ratio}

A profitability ratio is a ratio that reflects the outcome of all financial policies and operational decisions [3]. Return on assets is one of the measuring instruments of this ratio with the formula:

$$
\text { ROA }=\frac{\text { Net Profit After Tax }}{\text { Total Assets }}
$$

\section{Activity Ratio}

Activity ratio is a ratio that shows how quickly a company converts the efficiency level of its asset utilization (such as sales, receivables, inventory, and accounts receivable) into cash [4]. Total asset turnover is one of the measuring instruments of this ratio with the formula:

$$
\text { TATO }=\frac{\text { Sales }}{\text { Total Assets }}
$$

\section{A. Relationships Between Variables}

The relationship between variables or often known relationships between two variables, namely free variables with bound variables is usually used in regression analysis.

\section{B. Previous Research}

There have been several previous studies related to this topic. Astuti, Manik, and Munthe [1] found that NWC and DER did not effect on stock returns, while ROA influenced stock returns. Then Bintara and Tanjung [5] found ROA and PER have a positive effect on stock returns, while DER affects stock returns. Then, Mayasari and Anggraini [6] found that TATO and PER had a positive and significant impact on stock returns, while ROA had no significant effect on stock returns. Dirgasiwi, Dewi, and Gustyana [7] found that ROA and DER had no significant effect on stock returns, while Wayan and Anom [8] found PER had an insignificant negative effect on stock returns. Furthermore, Abdat [9] found that ROA negatively affects the return of shares, while DER has a significant negative effect on stock returns.

\section{Research Framework}

Based on background, problem formulation, research objectives, and library studies, the conceptual framework of this research is described:

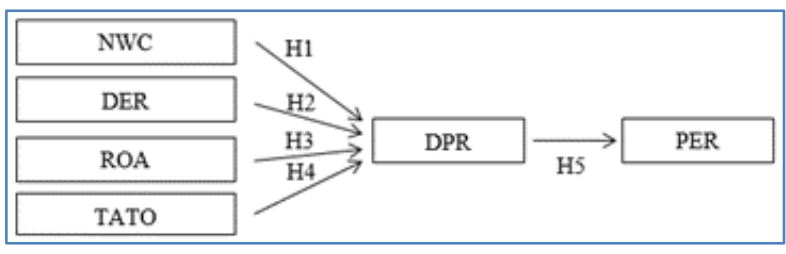

Fig-5: Theoretical Thought Frameworks

\section{The Hypothesis Development}

According to Sekaran and Bougie [10], the hypothesis can be defined as a temporary, but testable, statement that predicts what to find in empirical data. As for the hypothesis to be tested, as follows:

1. NWC has a positive effect on Stock Return.

2. DER negatively affects Stock Return.

3. ROA has a positive effect on Stock Return.

4. TATO negatively affect Stock Return.

5. Return of Shares negatively affects PER.

\section{RESEARCH METHODS}

Research Types, Samples, Measurement Variables

This study used the causal method, with a population of 18 companies and sampling techniques using the purposive sampling method, so obtained 8 companies. The following criteria are used for sampling:

1) Construction and Building Sub-Sector Companies listed on the Indonesia Stock Exchange for the period 2015-2019.

2) Construction and Building Sub-Sector Companies that distributed consecutive dividends on the Indonesia Stock Exchange for the period 20152019.

3) Construction and building sub-sector companies that have financial price earning ratio (PER) data during the period 2015-2019. 
Pungky Soleha Millenianingsih \& Bambang Mulyana., Saudi J Bus Manag Stud, Jan, 2021; 6(1): 1-9

Measurement Variables

Multiple Linear Analysis Test

Multiple Linear Regression aims to measure the intensity of the relationship between two or more variables and make an approximate prediction of the value of $\mathrm{Y}$ over $\mathrm{X}$. Multiple linear regression calculations are calculated as follows:

$$
Y=a+b 1 X 1+b 2 X 2+b 3 X 3+b 4 X 4+\varepsilon
$$

\section{Description:}

$\mathrm{Y}=$ Dividend Payout Ratio

$\boldsymbol{a}=$ Constant

$b 1, b 2, b 3, b 4=$ Regression Coefficient

$\mathrm{X} 1$ = Net Working Capital

$\mathrm{X} 2$ = Debt to Equity Ratio

X3 = Return On Assets

$\mathrm{X} 4=$ Total Assets Turnover

$\varepsilon=$ Standard error

\section{Simple Linear Analysis Test}

Simple linear regression is used to determine whether or not there is a linear relationship between one independent variable $(\mathrm{X})$ and a dependent variable $(\mathrm{Y})$. Multiple linear regression calculations are calculated as follows:

$$
Y=a+b_{1} \mathbf{X}_{1}+\varepsilon
$$

\section{Description}

$$
\begin{aligned}
& \mathrm{Y}=\text { Price Earning Ratio } \\
& \boldsymbol{a}=\text { Constant } \\
& b 1=\text { Regression Coefficient } \\
& \mathrm{X} 1=\text { Dividend Payout Ratio } \\
& \varepsilon=\text { Standard error }
\end{aligned}
$$

\section{RESULTS AND DISCUSSIONS Descriptive Statistical Analysis}

Descriptive statistics are to get an overview of the data so that it is easier to read. In descriptive statistics are generally displayed maximum, minimum, mean (mean) and standard deviation numbers.

Table-1: Descriptive Statistics

\begin{tabular}{|l|c|c|c|c|c|}
\hline & $\mathbf{N}$ & Minimum & Maximum & Mean & Std. Deviation \\
\hline NWC & 40 & -538088000000 & 15303544480000 & 4016573432014 & 4083646853206 \\
\hline DER & 40 & 68,85 & 3546,56 & 298,43 & 537,15 \\
\hline ROA & 40 & $-10,83$ & 14,02 & 3,67 & 3,50 \\
\hline TATO & 40 & 25,60 & 180,47 & 64,09 & 28,59 \\
\hline DPR & 40 & 0,31 & 141,75 & 37,50 & 31,35 \\
\hline PER & 40 & 1,48 & 48,23 & 16,00 & 10,97 \\
\hline
\end{tabular}

Source: Data processed with SPSS v.26 (2020)

The results of statistical analysis in table 1 can be found that the variable market value measured through the Price Earning Ratio (PER) shows a minimum value of $1.48 \%$, the maximum value is $48.23 \%$, and the mean value is $16.00 \%$ which means that the average value range with the maximum value is wider than the average value range with the minimum value, then PER in construction and building sector companies for the period 2015-2019 is mostly below average and the standard deviation of $10.97 \%$ which means that the value is less than the mean/average value. This indicates that per variables in this study do not vary or do not vary. Stock Return variable data as measured through the Dividend Payout Ratio (DPR) shows a minimum value of $0.31 \%$, a maximum value of $141.75 \%$, and a mean value of $37.50 \%$ which means that the range of average values with a maximum value is wider than the average value range with a minimum value, then the DPR in construction and building sector companies during the period 2015-2019 is mostly below average and the standard deviation of $31.35 \%$ which means that the value is less than the mean/average value. This indicates that the variables of the House of Representatives in this study do not vary or do not vary. Liquidity variable data as measured through the Company's Net Working Capital (NWC) shows a minimum value of $(-538,088,000,000)$, a maximum value of $15,303,544,480,000$, and a mean value of
$4,016,573,432,014$ which means that the range of mean values with a maximum value is wider than the range of average values with a minimum value, nwc in construction and building sector companies during the period 2015-2019 is mostly below average and the standard deviation of 4,083,646,853,206 which means that the value is greater than the mean / average value. This indicates that the NWC variables in this study vary or vary. Solvency variable data measured through the company's Debt to Equity (DER) shows a minimum value of $68.85 \%$, the maximum value is $3546.56 \%$, and the mean value is $298.43 \%$ that the average value range with the maximum value is wider than the average value range with the minimum value, then DER in construction and building sector companies during the period 2015-2019 is mostly below average and the standard deviation of $537.15 \%$ which means that the value is greater than the mean/average value. This indicates that the DER variables in this study varied or varied. Profitability variable data measured through the company's Return On Assets (ROA) shows a minimum value of $-10.83 \%$, the maximum value is $14.02 \%$, and the mean value is $3.67 \%$ which means that the average value range with the maximum value is wider than the average value range with the minimum value, then the ROA in construction and building sector companies during the period 2015-2019 is mostly below average and the standard deviation of $3.50 \%$ which means that 
Pungky Soleha Millenianingsih \& Bambang Mulyana., Saudi J Bus Manag Stud, Jan, 2021; 6(1): 1-9

the value is less than the mean/average value. This indicates that the ROA variables in this study do not vary or do not vary. Activity variable data measured through the company's Total Assets Turn Over (TATO) shows a minimum value of $25.60 \%$, the maximum value is $180.47 \%$, and the mean value is $64.09 \%$ which means that the average value range with the maximum value is wider than the average value range with the minimum value, then TATO in construction and building sector companies during the period 2015-2019 is mostly below average and the standard deviation of $28.59 \%$ which means that the value is less than the mean/ average value. This indicates that the variables of TATO in this study do not vary or do not vary.

\section{A. Model 1 Results}

\section{Classic Assumption Test}

\section{Test Normality}

Normality test in this study using One-Sample Kolmogorov Smirnov Test approach with $\alpha=0.05$.

Table-2: One-Sample Kolmogorov-Smirvnov Model 1 \begin{tabular}{|l|l|}
\hline Signifikansi & 0,200 \\
\hline
\end{tabular}

Source: Data processed with SPSS v.26 (2020)

Based on Table 2, the result of significance is 0.200 greater than alpha by 0.05 so that the data is distributed normally.

\section{Multicollinearity Test}

Multicollinearity test using tolerance and VIF value approach. There are no symptoms of multicollinearity when the tolerance value should be more than 0.1 and VIF less than 10.

Table-3: Uji Multicollinearity Model 1

\begin{tabular}{|c|c|c|}
\hline \multirow{2}{*}{ Model } & \multicolumn{2}{|c|}{ Collinearity Statistics } \\
\cline { 2 - 3 } & Tolerance & VIF \\
\hline NWC & 0,755 & 1,325 \\
\hline DER & 0,452 & 2,214 \\
\hline ROA & 0,395 & 2,532 \\
\hline TATO & 0,624 & 1,601 \\
\hline
\end{tabular}

Source: Data processed with SPSS v.26 (2020)

Based on table 3 can be interpreted, there are no symptoms of multicollinearity or absence of correlation between independent variables in this study.

\section{Heterosceticity Test}

Heterosceticity tests are intended to see if there is variance inequality from one residual to observation to another. The White test proposes to regress the residual value of squares $\left(\mathrm{U}^{2} \mathrm{t}\right)$ against independent variables, quadratic independent variables, and independent variable multiplication [11].

The criteria for decision making in this test is to look at the value of $C^{2}$, provided that if $C^{2}$ calculates the $<\mathrm{C}^{2}$ table then there is no heteroscedasticity.
Table-4: Uji White Model 1

\begin{tabular}{|c|c|}
\hline R Square & Adjusted R Square \\
\hline 0,206 & 0,115 \\
\hline
\end{tabular}

Source: Data processed with SPSS v.26 (2020)

Based on table 4 results of the heteroscedasticity test obtained adjusted $\mathrm{R}$ square value of 0.115 times $n$ by 40 , then obtained value 4.6 or ChiSquare calculate. If the value of chi-square calculates < chi-square table then it means that there are no symptoms of the heteroscedasticity, where the value of the chi-square table obtained is 7.815 .

\section{Autocorrelation Test}

Autocorrelation tests were used to determine whether in multiple linear regression models there was a correlation between disruptive errors in the t-period and errors in the $\mathrm{t}-1$ (previous) periods.

In this study autocorrelation test using Durbin Watson test (DW test), Durbin Watson value is calculated first, then compare with upper limit value $(\mathrm{dU})$ and lower limit value (dL) with the basic decision making in Durbin Watson test, which is:

1. $\mathrm{dW}<\mathrm{dL}$, there is a positive autocorrelation.

2. $\mathrm{dL}<\mathrm{dW}<\mathrm{dU}$, inconclusive.

3. $\mathrm{dU}<\mathrm{dW}<4-\mathrm{dU}$, no autocorrelation.

4. $-\mathrm{dU}<\mathrm{dW}<4-\mathrm{dL}$, inconclusive.

5. $\mathrm{dW}>4-\mathrm{dL}$, there is a negative autocorrelation.

Table-5: Durbin Watson Test Model 1 \begin{tabular}{|l|l|}
\hline Durbin Watson & 1,803 \\
\hline
\end{tabular}

Source: Data processed with SPSS v.26 (2020)

Based on table 5 results known dW value of 1.803. Furthermore, the result of this value will be compared with the value of the table $\mathrm{dW}$ with a significance of $5 \%$, where the number of data $\mathrm{N}=40$ and the number of independent variables $K=4$ then obtained the value $\mathrm{dU}$ (upper limit) of 1.2848 and the value 4 - dU (upper limit) of 2.2791. Because the $\mathrm{dW}$ result is located between $\mathrm{dU}<\mathrm{dW}<4-\mathrm{dU}$, so it can be interpreted that there is no autocorrelation.

\section{Model Conformity Test \\ Determination Coefficient Test $\left(\mathbf{R}^{2}\right)$}

The coefficient of determination or $\mathrm{R}$ Square aims to predict and see how large independent variables can explain dependent variables. The coefficient of determination is expressed in percentages by the formula:

$$
K d=\mathbf{r}^{2} \times 100 \%
$$

\section{Description \\ $\mathrm{Kd}=$ Coefficient of Determination \\ $\mathrm{R}=$ Correlation Coefficient}


Pungky Soleha Millenianingsih \& Bambang Mulyana., Saudi J Bus Manag Stud, Jan, 2021; 6(1): 1-9

Table-6: Determination Coefficient Test $\left(\mathbf{R}^{2}\right)$ Model 1

\begin{tabular}{|c|c|}
\hline R Square & Adjusted R Square \\
\hline 0,300 & 0,220 \\
\hline
\end{tabular}

Source: Data processed with SPSS v.26 (2020)

Based on table 6 results can be known as the Adjusted R Square value of 0.220 . This means that NWC, DER, ROA, and TATO can explain the dividend policy (DPR) by $22 \%$. This is $78 \%$ explained by variables or other factors not included in this study.

\section{F ANOVA Test}

Test $\mathrm{F}$ aims to determine the suitability of the regression model used as an analysis tool. F ANOVA test can be done if:

- F calculate $>\mathrm{F}$ table and $\mathrm{Sig}<0.05$ then $\mathrm{Ho}$ is rejected, meaning significant regression model.

- F calculates < F table and Sig > 0.05 then Ho is accepted, meaning the regression model is not significant.

Table-7: F ANOVA Test Model 1F

\begin{tabular}{|c|c|}
\hline & Sig. \\
\hline 3,757 & 0,012 \\
\hline
\end{tabular}

Source: Data processed with SPSS v.26 (2020)

Based on table 4.8 known $\mathrm{f}$ calculated value of 3.244 with a significance level of 0.023 . The value of $F$ is compared to the $\mathrm{F}$ of the table. The table $\mathrm{F}$ value of 2.64 is measured by degrees of freedom $(\mathrm{k}-1)=5-1=$ 4 and $(\mathrm{n}-\mathrm{k})=40-5=35$ where $\mathrm{k}=$ the number of dependent and independent variables, and $\mathrm{n}=$ the number of samples. Furthermore, the results obtained that $\mathrm{F}$ calculates greater than $\mathrm{F}$ table $(3.757>2.64)$ as well as significant value less than $0.05(0.012<0.05)$, then the regression model in this study is feasible and can be used to predict the influence of variables NWC, DER, ROA, TATO on stock return (DPR).

\section{Multiple Linear Analysis Test}

The test results of multiple linear regression analysis can be seen in table 8 below:

Table-8: Multiple Linear Analysis Test Models 1

\begin{tabular}{|c|c|}
\hline Model & Unstandardized Coefficients \\
\hline & B \\
\hline (Constant) & 60,743 \\
\hline NWC & $-3,42$ \\
\hline DER & $-0,028$ \\
\hline ROA & $-2,540$ \\
\hline TATO & 0,129 \\
\hline
\end{tabular}

Source: Data processed with SPSS v.26 (2020)

Based on table 8 obtained regression equation as follows

DPR $=60,473-3,42$ NWC $-0,028$ DER $2,540 \mathrm{ROA}+0,129 \mathrm{TATO}$
The above regression equation has the meaning

1. Constants of 60.473 state that if NWC, DER, ROA, TATO have the number 0 , then the DPR is $60.473 \%$.

2. NWC has a coefficient of 3.42 with a negative direction which means the NWC negatively affects the DPR. This indicates that if there is an increase of $1 \%$ in the NWC, then the DPR will fall by $3.42 \%$. Assuming DER, ROA, and TATO values remain.

3. DER has a coefficient of 0.02 with a negative direction which means DER negatively affects the DPR. This indicates that with an increase of $1 \%$ in DER, then the DPR will fall by $0.028 \%$. Assuming NWC, ROA, and TATO values remain.

4. ROA has a coefficient of 2,540 with a negative direction which means ROA negatively affects the DPR. This indicates that a $1 \%$ increase in ROA, resulting in the DPR falling by $2.540 \%$. Assuming NWC, DER, and TATO values remain.

5. TATO has a coefficient of 0.129 with a positive direction which means TATO has a positive effect on the DPR. This indicates that the $1 \%$ increase in TATO will be followed by a $0.129 \%$ increase in DPR. Assuming the NWC, DER, and ROA values remain.

\section{Hypothesis Test}

The t-test aims to determine the significance of the partial influence of NWC, DER, ROA, TATO on stock returns as well as the partial effect of stock returns on PER. The criteria in a test with a t-test are to compare a $\mathrm{t}$ table with a calculated $\mathrm{t}$ value $(\alpha=0.05)$ with the following formula:

$$
D f=n-k
$$

\section{Description}

$n=$ Number of observations /regression-forming sample $k=$ Number of variables (free + bound)

- If the significance level of the t-test $<\mathrm{t}$ table, then $\mathrm{Ho}$ is rejected and $H a$ is accepted, it means that partially the influence of NWC, DER, ROA, TATO on stock returns (DPR). And the stock return (DPR) to PER is not significant.

- If the level of significance of the t-test $>\mathrm{t}$ table, then $H o$ is accepted and $\mathrm{Ha}$ is rejected, it means that partially the effect of NWC, DER, ROA, TATO on stock returns (DPR). And stock returns (DPR) on PER is significant.

Table-9: Hypothesis Test (T test) Model 1

\begin{tabular}{|c|c|c|}
\hline Model & t & Sig \\
\hline (Constant) & 3,501 & 0,001 \\
\hline NWC & $-2,736$ & 0,010 \\
\hline DER & $-2,300$ & 0,028 \\
\hline ROA & $-1,264$ & 0,215 \\
\hline TATO & 0,657 & 0,516 \\
\hline
\end{tabular}

Source: Data processed with SPSS v.26 (2020) 
Pungky Soleha Millenianingsih \& Bambang Mulyana., Saudi J Bus Manag Stud, Jan, 2021; 6(1): 1-9

In table 9, the following results are obtained

1. Net Working Capital (NWC) had a calculated t of 2,736 less than the $t$ table of $2.028(-2.736<2.028)$ with a significant value of 0.010 less than $0.05(0.010$ $<0.05)$. This indicates net working capital has a negative and significant effect on Stock Return.

2. Debt to Equity Ratio (DER) has a calculated $t$ of 2,300 less than the table $2.028(-2.300<2.028)$ with a significant value of 0.028 less than $0.05(0.028<$ 0.05). This indicates the Debt to Equity Ratio has a negative and significant effect on Stock Return.

3. Return On Assets (ROA) has a calculated t of -1.264 less than $2.028(-1.264<2.028)$ with a significant value of 0.215 greater than $0.05(0.215>0.05)$. This indicates that Return On Assets has a negative and insignificant effect on Stock Return.

4. Total Assets Turn Over (TATO) had a calculated t of 0.657 less than 2,028 (0.657< 2.028) with a significant value of 0.516 greater than $0.05(0.516>$ 0.05). This indicates that Total Assets Turn Over has a positive and insignificant effect on Stock Return.

\section{B. Model 2 Results}

\section{Classic Assumption Test}

\section{Test Normality}

Data can be declared normal if the significance value is greater than 0.05 . Therefore, the normality test will be retested to get the normality level after outlier elimination.

Table-10: One Sample Kolmogorov Smirnov Model 2 \begin{tabular}{|l|l|}
\hline Signifikansi & 0,062 \\
\hline
\end{tabular}

Source: Data processed with SPSS v.26 (2020)

Based on table 10 obtained significance of 0.062 , so that data is distributed normally because the value of significance is greater than alpha.

\section{Multicollinearity Test}

The following are the results of the model 2 multicollinearity test, as follows:

Table-11: Multicollinearity Test Model 2

\begin{tabular}{|c|c|c|}
\hline \multirow{2}{*}{ Model } & \multicolumn{2}{|c|}{ Collinearity Statistics } \\
\cline { 2 - 3 } & Tolerance & VIF \\
\hline DPR & 1,000 & 1,000 \\
\hline
\end{tabular}

Source: Data processed with SPSS v.26 (2020)

Based on table 11 independent variable tolerance values the number is more than 0.1 and the VIF value is less than 10 . So it can be interpreted, there are no symptoms of multicollinearity or the absence of correlation between independent variables.

\section{Heterosceticity Test}

Heterosceticity test using the number method approach that is Spearman Rho correlation. In order not to occur symptoms of heteroscedasticity then the significance must be greater than 0.05 . If the value of significance is less than 0.05 then the conclusion is that heteroskedasticity occurs.

Table-12: Spearman Rho Correlation Test Model 2

\begin{tabular}{|c|c|}
\hline & Sig \\
\hline DPR & 0,955 \\
\hline
\end{tabular}

Source: Data processed with SPSS v.26 (2020)

Based on table 12 obtained a significant value variable of more than 0.05 . The significant value of the Variable Dividend Payout Ratio is $0.955>0.05$. So it can be interpreted in the second model this does not occur symptoms of heteroscedasticity.

\section{Autocorrelation Test}

The following are the results of the model 2 autocorrelation test, as follows:

\section{Table-13: Durbin Watson Test Model 2}

\begin{tabular}{|l|l|}
\hline Durbin Watson & 1,542 \\
\hline
\end{tabular}

Source: Data processed with SPSS v.26 (2020)

Based on table 13 obtained dW value of 1.542 . Furthermore, the result of this value will be compared with the value of the table $\mathrm{dW}$ with a significance of $5 \%$, on the number of data $\mathrm{N}=38$ and the number of independent variables $\mathrm{K}=1$ then obtained the value $\mathrm{dU}$ (upper limit) of 1.5348 and the value $4-\mathrm{dU}$ of 2.4652 . Because the $\mathrm{dW}$ result is located between $\mathrm{dU}<\mathrm{dW}<4-$ $\mathrm{dU}$, so it can be interpreted that there is no autocorrelation.

\section{Model Conformity Test}

\section{Determination Coefficient Test $\left(\mathbf{R}^{2}\right)$}

The results of the determination coefficient test or R Square can be seen in table 14 below:

Table-14: Determination Coefficient Test $\left(\mathbf{R}^{2}\right)$ Model 2

\begin{tabular}{|c|c|}
\hline R Square & Adjusted R Square \\
\hline 0,418 & 0,174 \\
\hline
\end{tabular}

Source: Data processed with SPSS v.26 (2020)

Based on the table above, the value of $\mathrm{R}$ Square $\left(R^{2}\right)$ is $0.418 . \mathrm{Kd}=\mathrm{r}^{2} \times 100 \%$ i.e. $0.418 \times 100 \%=41.8 \%$. That is, independent variables can explain the behavior of dependent variables by $41.8 \%$ while the remaining $58.2 \%$ is explained by other variables not included in this study such as Debt to Asset Ratio (DAR), Return on Equity (ROE), Inventory Turnover (ITO) and so on.

\section{F ANOVA Test}

F ANOVA test results can be seen in table 15 below:

Table-15: F ANOVA Test Model 2

\begin{tabular}{|c|c|}
\hline F & Sig. \\
\hline 7,609 & 0,009 \\
\hline
\end{tabular}

Source: Data processed with SPSS v.26 (2020)

Based on table 15 , the calculated $\mathrm{f}$ value is obtained by 7.609 with a significance level of 0.009 . 
Pungky Soleha Millenianingsih \& Bambang Mulyana., Saudi J Bus Manag Stud, Jan, 2021; 6(1): 1-9

Meanwhile, table $\mathrm{F}$ values of 4.10 are measured by degrees of freedom $(\mathrm{k}-1)=2-1=1$ and $(\mathrm{n}-\mathrm{k})=38-$ $2=36$ where $\mathrm{k}=$ number of dependent and independent variables, and $\mathrm{n}=$ number of samples. Derived calculated $\mathrm{F}$ result is greater than table $\mathrm{F}(7.609>4.11)$ and the value of significantly less than alpha $(0.009<$ $0.05)$. Thus, it is interpreted that the regression model in the second model research is feasible to predict the influence of variable stock returns (DPR) on the Price Earning Ratio (PER).

\section{Simple Linear Analysis Test}

The results of a simple linear regression analysis test can be seen in table 16 below:

Table-16: Simple Linear Analysis Test Model 2

\begin{tabular}{|c|cc|}
\hline $\begin{array}{c}\text { Mode } \\
\mathbf{l}\end{array}$ & \multicolumn{2}{|c|}{ Unstandardized Coefficients } \\
\cline { 2 - 3 } & \multicolumn{2}{|c|}{ B } \\
\hline \multicolumn{2}{|c|}{ (Constant) } & 19,810 \\
\hline \multicolumn{2}{|c|}{ DPR } & $-0,156$ \\
\hline
\end{tabular}

Source: Data processed with SPSS v.26 (2020)

Based on table 4.17 obtained regression equation, as follows: PER = 19,810 - 0,156 DPR

\section{The regression equation above has the meaning}

1. Constants of 19,810 state that if the Dpr has the number 0 , then it is $19,810 \%$.

2. DPR has a coefficient of 0.156 with a negative direction which means that the DPR has a negative effect on the PER. This indicates that if there is an increase of $1 \%$ in the DPR, then PER will fall by $0.156 \%$.

\section{Hypothesis Test}

The results of the hypothesis test can be seen in table 17 below:

Table-17: Hypothesis Test (T test) Model 2

\begin{tabular}{|c|c|c|}
\hline Model & $\mathbf{t}$ & Sig \\
\hline (Constant) & 8,519 & 0,000 \\
\hline DPR & $-2,758$ & 0,009 \\
\hline
\end{tabular}

Source: Data processed with SPSS v.26 (2020)

\section{In table 17, the following results are obtained}

1. Stock Return has a calculated t of $-2,758$ less than the table $t$ of 2,026 with a significant value of 0.009 less than the alpha. This indicates that The Stock Return has a significant negative effect on the Price Earning Ratio (PER).

\section{The Effect of Net Working Capital on Stock Returns}

Based on the results of this study, it can be known that Net Working Capital has a significant negative effect on Stock Return. The results of this study are in line with previous research conducted by Astuti, Manik, Munthe [1]. This means that high Net Working Capital indicates that the company has current assets greater than current debt. This indicates that with high net working capital value indicates that the current asset management is not running well, so many current assets are unemployed because the company does not maximize existing assets. High cash may be used to pay other liabilities, while high inventory indicates goods are not sold, then high receivables indicate bills are difficult to collect to reduce the company's potential for profit, even though the profit is necessary to pay dividends (stock return).

\section{The Effect of Debt to Equity Ratio on Stock Return}

It is known that the Debt to Equity Ratio negatively and significantly affects Stock Return. The results of this research are in line with previous research conducted by Bintara and Tanjung [5]. It is commonly known that the financing patterns of construction and building companies are largely financed by debt for the work of their projects so that the company has a highinterest expense. Thus, the profits obtained by the company must first be used to pay interest to creditors and other obligations to the bank. Thus the remaining paid to the shareholders (stock return) is relatively small; therefore it has a negative and significant effect.

\section{The Effect of Return on Assets on Stock Return}

It is known that Return on Assets has a negative and insignificant effect on Stock Return. The results of this study are in line with previous research conducted by Aldiena and Hakim [12]. Companies that book high Returns On Assets value because the company earns a good profit, but the profit is used to pay interest to creditors and obligations to the bank first. Thus, the higher the Return on Assets, the company will increase the fulfillment of its obligations to creditors. Thus the return of shares for shareholders is the remaining fulfillment of obligations to creditors.

\section{The Effect of Total Assets Turn Over on Stock Return \\ Obtained that Total Assets Turn Over has an} insignificant positive effect on Stock Return. The results of this study are in line with previous research conducted by Himmatussuhra, Mardani, Khoirul [13]. This indicates that the faster the Total Assets Turn Over, the faster the company will get cash. However, as explained earlier, cash is used in advance to fulfill obligations to creditors so that total assets turn over does not have a significant influence on Stock Return.

\section{The Effect of Stock Return on Price Earning Ratio}

It is known that Stock Return negatively and significantly affects the price earning ratio. The results of this study are in line with previous research conducted by Wardani, Masithoh, and Soegiartio [14]. Share Return is used as one of the benchmarks of a company, in the distribution of the company's net profit on operating activities and is the obligation of the company. This is because the company must meet the interests of investors, who want a high dividend distribution (Stock Return). The high dividend payment (Stock Return) given will result in a small retained profit used to 
Pungky Soleha Millenianingsih \& Bambang Mulyana., Saudi J Bus Manag Stud, Jan, 2021; 6(1): 1-9

strengthen the company's operations. The small value of retained earnings caused negative sentiment from investors in the capital market so that the share price declined which would be followed by a decrease in the Price Earning Ratio.

\section{CONCLUSION}

Based on the results and discussions that have been described before, can be drawn some conclusions as follows:

1. NWC has a negative and significant effect on Stock Return.

2. DER has a negative and significant influence on Stock Return.

3. ROA has a negative and insignificant effect on Stock Return.

4. TATO have a positive and insignificant effect on Stock Return.

5. Stock Return has a negative and significant effect on the Price Earning Ratio.

\section{REFERENCES}

1. Astuti, P., Tumpal, M., dan Inge Lengga Sari Munthe. (2017). "Pengaruh Net Working Capital, Price To Book Value, Debt to Equity Ratio Dan Return On Assets Terhadap Return Saham Pada Perusahaan Food And Beverage Yang Terdaftar Di Bursa Efek Indonesia Periode 2013-2016”. Repository Umrah.

2. Davis, C. E., \& Davis, E. (2019). Managerial accounting. John Wiley \& Sons.

3. Brigham, E.F., dan, J.F. Houston. (2014). Essential of Financial Management. Singapore: Cengage Learning.

4. Mayo, H.B. (2012). An Introduction to Institutions, Management, \& Investments, $10^{\text {th }} \mathrm{ed}$. South Western: Cengage Learning.

5. Bintara, R., dan Putri Renalita Sutra Tanjung. (2019). "Analysis of Fundamental Factors on Stock Return". International Journal of Academic Research in Accounting, Finance and Management Sciences, 9(2), 49-64.

6. Mayasari, R. P., dan Anggraini, R. (2016). "Pengaruh Rasio Aktivitas, Rasio Profabilitas, Dan Rasio Pasar Terhadap Return Saham Perusahaan
Sub Sektor Telekomunikasi Di Bursa Efek Indonesia". Jurnal Manajemen dan Bisnis Sriwijaya, 14(1)

7. Dirgasiwi, D. F., Andrieta, S.D., dan Tieka Trikartika Gustyana. (2016). "The Effect of Inflation, Exchange Rate, Return on Assets (ROA), And Debt to Equity Ratio (DER) On Stock Returns: A Case Study on Building Construction Sub-Sector Companies Listed On Indonesia Stock Exchange Period 2011-2015". E-Proceeding of Management, 3(3).

8. Iwayan, J., \& Anom, P. I. B. (2020). The effect of financial performance on stock return at manufacturing company of Indonesia stock exchange. Russian Journal of Agricultural and Socio-Economic Sciences, 97(1).

9. Abdat, F. A. (2016). "Pengaruh Faktor-Faktor Fundamental Dan Faktor Eksternal Terhadap Return Saham Pada Saham LQ-45 Di Bursa Efek Indonesia Periode 2007-2010". Jurnal Ilmiah Manajemen dan Bisnis, 2(3).

10. Sekaran, U., \& Bougie, R. (2016). Research methods for business: A skill building approach. John Wiley \& Sons.

11. Ghozali, I. (2018). Aplikasi Analisis Multivariat dengan Program SPSS 25, Cetakan IX. Semarang: Badan Penerbit Universitas Diponegoro.

12. Aldiena, E., \& al Hakim, M. H. (2019). The Impact of Companies' Internal Factors On The Performance of Their Stock Returns. Journal of Islamic Economic Laws, 2(1), 120-149.

13. Himmatussuhra, H., Mardani, R. M., \& ABS, M. K. (2018). Pengaruh eps, roe, der dan tato terhadap return saham pada perusahaan perbankan yang terdaftar di bei. Jurnal Ilmiah Riset Manajemen, 7(14).

14. Wardani, A.A., Rina, M., dan, E. S. (2019). Anrialisis Current Ratio, Return Equity, Price Earning Ratio Terhadap Return Saham Pada Sektor Industri Dasar Dan Kimia Yang Tercatat Di Bursa Efek Tahun 2014-2016. e-Jurnal Untag-smd.

15. Syamsuddin, L. (2011). Manajemen Keuangnan Perusahaan: Konsep Keputusan. Jakarta: Rajawali Pers. 